\title{
Efficacy and Optimal Time of Oropharyngeal Topical $10 \%$ Lignocaine Spray Before Induction of Anaesthesia in Attenuating the Pressor Response to Direct Laryngoscopy and Endotracheal Intubation.
}

\author{
Dr. Faisal Mushfeen Qureshi ${ }^{1}$, Dr. Sampathila Padmanabha ${ }^{2}$, \\ Dr. Habib Rahaman ${ }^{3}$, Dr. Sheikh Imran ${ }^{4}$, Dr. Pratibha Ram Mohan ${ }^{5}$ \\ ${ }^{1}$ Department of Anaesthesia and Critical care, Yenepoya Medical College, Yenepoya University, Mangalore, Karnataka,India. \\ ${ }^{2}$ Professor \& Head, of Anaesthesia and Critical care, Yenepoya Medical College, Yenepoya University, Mangalore, Karnataka,India. \\ ${ }_{3}^{3}$ Associate Professor, of Anaesthesia and Critical care, Yenepoya Medical College, Yenepoya University, Mangalore, Karnataka,India. \\ ${ }^{4,5}$ Post graduate final year, of Anaesthesia and Critical care, Yenepoya Medical College, Yenepoya University, Mangalore, Karnataka,India
}

\begin{abstract}
The study aimed to ascertain the efficacy of oropharyngeal topical 10\% lignocaine spray applied prior to induction of anaesthesia and also to determine the optimal time for spraying to attenuate pressor response to laryngoscopy and endotracheal intubation. 80 patients of either sex, in the age group of 20-60 years (ASA I \& II) undergoing different elective surgical procedures under general anaesthesia were taken up for the study. 10 puffs of Lignocaine 10\% sprayed 1 min before induction in Group I, 3 min before induction in Group 2, 5 min before induction in Group 3 and normal Saline in Group 4 as control. Heart rate(HR), systolic (SBP), diastolic (DBP) and mean arterial pressure (MAP) were measured at baseline, after intubation, after 1min, 3 min and 5 min following intubation. There was statistically significant increase in HR, systolic, diastolic and MAP in control group when compared to baseline as well as to study groups. Following laryngoscopy and intubation attenuation of pressor response did not show a significant difference at $1 \mathrm{~min}$, $3 \mathrm{~min}$ and $5 \mathrm{~min}$ of $10 \%$ lignocaine spray within study groups. Lignocaine 10\% when sprayed to the oropharynx prior to induction of anaesthesia attenuated the pressor response to laryngoscopy and intubation irrespective of timing of the spray.
\end{abstract}

Keywords: Endotracheal Intubation, Lignocaine spray (10\%), Laryngoscopy, Pressor response, Systolic Blood pressure (SBP), Diastolic blood pressure (DBP), Mean arterial pressure (MAP).

\section{Introduction}

In practice of anaesthesia, laryngoscopy and tracheal intubation forms the basis of controlling the patient's airway during general anaesthesia or for artificial ventilation. Laryngoscopy and endotracheal intubation has been a challenging procedure due to associated cardiovascular changes called pressor response. This response includes widespread release of norepinephrine from adrenergic nerve terminals and secretion of epinephrine from the adrenal medulla ${ }^{1}$. In adults and adolescents, the more common response to this airway manipulation is hypertension and tachycardia, mediated by the cardio-accelerator nerves and sympathetic chain ganglia.

In addition to activation of the autonomic nervous system, laryngoscopy and endotracheal intubation result in stimulation of the central nervous system (CNS), as evidenced by increases in electroencephalographic activity, cerebral metabolic rate, and cerebral blood flow $(\mathrm{CBF})^{2-5}$.

Pressor response has deleterious effects on patients with preexisting hypertension, ischaemic heart disease which may lead to tachycardia, arrhythmia, cerebrovascular accidents etc.

Several drugs like lignocaine ${ }^{6}$, clonidine ${ }^{7}$, fentanyl ${ }^{8}$ and betablockers ${ }^{9}$, has been tried to control the pressor response to laryngoscopy and intubationbut it is not possible to completely abolish the response.

The present study was undertaken to study the efficacy of oropharyngeal topical $10 \%$ lignocaine spray in attenuating the pressor response as well as to find the optimal timing of application of lignocaine spray.

\section{Materials And Methods:}

We conducted a prospective, randomized, controlled study with 80 patients of ASA grade I \& II, of either sex, aged between 20 and 60 years, undergoing routine elective surgical procedures under general anaesthesia. Study was conducted after getting institutional ethical committee approval and informed consent from all the patients. We excluded patients with uncontrolled hypertension, significant hepatic or renal disease, predicted difficult intubation, history of hypersensitivity to amide local anaesthetics, seizure disorder and patients taking any systemic medications.After pre-operative evaluation and necessary routine investigations, premedicated with tab Ranitidine 150mg, and tab Lorazepam 1mg 2 hour before induction. Glycopyrollate $0.2 \mathrm{mg}$ was administered intramuscularly $30 \mathrm{~min}$ before induction. Routine monitoring was done using 
noninvasive blood pressure (NIBP), electrocardiogram (ECG), pulse oximeter (SPO2). Baseline values of heart rate(HR), systolic blood pressure(SBP), diastolic blood pressure(DBP) and mean arterial pressure(MAP) were measured before spraying with lignocaine $(10 \%)$.

Patients were randomly allotted into one of the four groups using lottery method; each group consisted of 20 patients. In group 1, patients were subjected to lignocaine $10 \%$ spray 1 min before induction, in group 2 lignocaine $10 \%$ spray was administered $3 \mathrm{~min}$ before induction, similarly in group 3 lignocaine $10 \%$ spray was administered at $5 \mathrm{~min}$ before induction, patients in group 4 were administered normal saline spray who served as control.Lignocaine $10 \%$ oral spray was administered in the sitting position by asking the patient to fully open their mouth and using a disposable spray canula into the mouth without using laryngoscope, a total of 10 puffs ( 2 puffs to soft palate, 3 puffs to posterior oropharyngeal wall, 2 puffs to palatopharyngeal arch and 3 puffs to posterior $3^{\text {rd }}$ of tongue, each puff delivering $10 \mathrm{mg}$, resulting in a total dose of $100 \mathrm{mg}$ and not exceeding the toxic dose of $3-4 \mathrm{mg} / \mathrm{kg}$. All patients were induced with propofol $2 \mathrm{mg} / \mathrm{kg}$ followed by rocuronium $0.9 \mathrm{mg} / \mathrm{kg}$ to facilitate endotracheal intubation. Using Macintosh blade laryngoscopy and intubation was done by anesthesiologist having 5 years of experience. Patients with difficult intubation which require laryngoscopy more than 20 seconds and who require more than one attempt were excluded from the study. Fentanyl $2 \mu \mathrm{gs} / \mathrm{kg}$ was given as an analgesic. A second recording of HR, SBP, DBP and MAP were noted immediately after laryngoscopy and intubation, and then $1 \mathrm{~min}, 2 \mathrm{~min}, 3 \mathrm{~min}$ and $5 \mathrm{~min}$ intervals after laryngoscopy and intubation.

The results were subjected to statistical analysis using Student's unpaired ' $t$ 'test and ANOVA was used for overall differences. Any p value less than 0.05 were taken as statistically significant. SPSS version 17 was used for analysis.

\section{Results:} (Table 1)

There was no statistically significant difference in the demographic characteristics among the 4 groups

There was significant rise of heart rate in the control groupwhen compared to the baseline heart rate.There was also a statistically very highly significant $(p<0.001)$ difference compared to study groups $1,2,3$. However,among the study groups, change in the heart rate was not statistically significant (Tables $2 \& 3$ ). SBP, DBP and MAP showed statistically highly significant change $(p<0.001)$ in control group $(4)$ when compared to study groups and baseline. Moreover, there was statistically insignificant difference in SBP, DBP and MAP ( $p=$ $0.321, \mathrm{p}=0.772, \mathrm{p}=0.520$ ) respectively between groups $1,2,3$ (Tables $4-9$ ).

\section{Discussion:}

Laryngoscopy and intubation is associated with a sympathoadrenal response leading to increase in arterial blood pressure, heart rate and may also result in arrhythmias. This bears a particular significance in patients of cardiac condition like hypertension, patients with acute myocardial infarction ${ }^{1-5}$.

The laryngoscopy and endotracheal intubation(ET) intubation is considered to be a stronger stimulus than a surgical incision. The amount of pressor response is related to the force applied to the base of tongue, the duration of laryngoscopy.There have been many different ways tried to decrease the pressor response ranging from non-pharmacological methods like using $\mathrm{LMA}^{10}$, various types of laryngoscope blades like $\mathrm{McCoy}^{11}$ for doing laryngoscopy, to pharmacological methods like lignocaine, alpha-2 agonists, opioids, nitroglycerine, betablockers among others ${ }^{6-9,12}$.

Lignocaine has been tried as intravenous administration prior to laryngoscopy, mouth gargles in various concentration, sprays. The mechanism of action of lignocaine in blunting pressor response differs according to the method of administration. Local administration like gargles and sprays may be effective due to its local anaesthetic property at the base of tongue and pharyngeal walls preventing the receptor stimulation. The intravenous administration mainly acts by decreasing the cerebral blood flow and depression of myocardial contractility ${ }^{13}$. Abou-Madi etal ${ }^{14}$ have discussed the possible mechanisms to account for these observations with IV lignocaine. These include a direct myocardial depressant effect, a peripheral vasodilation effect and finally an effect on synaptic transmission.

In our study we used oropharyngeal topical $10 \%$ lignocaine sprayprior to inductionto determine the efficacy in attenuating the pressor response and optimal timing of spraying. Weused 10 puffs in total, each puffdelivering $10 \mathrm{mg}$, so total dose given was $100 \mathrm{mg}$. This dose is well below the toxic dose of lignocaine. We used glycopyrollate ${ }^{15} 0.2 \mathrm{mg}$ as a premedication which has been proved to be enhancing absorption, prolongs the analgesic action of lignocaine and has anti-sialagogue property. We found that the lignocaine spray was effective in attenuating pressor response (in terms of heart rate, systolic blood pressure, diastolic blood pressure and mean arterial pressure) in all the three groups receiving the drug in comparison to the group 4 which received normal saline and to the baseline values.

We performed a single laryngoscopy prior to endotracheal intubation whereas laryngoscopy was performed twice by Mostafa etal $^{16}$ because they administered the spray after induction, thus results are not 
comparable. Hamill etal ${ }^{17}$ compared topical lignocaine with I.V. lignocaine. In the topical group, after induction of anesthesia they performed laryngoscopy to spray the oropharynx, two minutes later, they performed another laryngoscopy for endotracheal intubation. While in other group they performed only one laryngoscopy and hence noxious stimuli were given twice in the topical group.Mostafa ${ }^{16}$ and Hamill ${ }^{17}$ in their respective studies had concluded that topical lignocaine is ineffective in preventing the pressor response. Takita etal $^{18}$ suggested that differing intervals between tracheal lignocaine and endotracheal intubation probably caused the inconsistent conclusion reported in other investigations and showed that endotracheal intubation performed two minutes after tracheal lignocaine attenuated the cardiovascular responses to endotracheal intubation M. Jain et al ${ }^{19}$ performed a study on lignocaine 10 percent spray to study its efficacy in attenuating the pressor response and found it to be effective in attenuating and not abolishing the response, we had similar findings in lignocaine being able to attenuate the pressor response, but they didn't study the optimal timing of the spray and they didn't use glycopyrrolate as a premedication.

\section{Conclusion}

We conclude that spraying oropharynx with 10 puffs $(100 \mathrm{mg})$ of topical $10 \%$ lignocaine is effective in blunting the pressor response to laryngoscopy and intubation when it is applied before induction of general anaesthesia irrespective of timing of the spray.

Table 1: Demographic characteristics (mean \pm SD) of four groups

\begin{tabular}{|l|l|l|l|l|l|}
\hline $\begin{array}{l}\text { Demographic } \\
\text { characteristics }\end{array}$ & $\begin{array}{l}\text { Group 1 } \\
(\mathbf{n}=\mathbf{2 0})\end{array}$ & $\begin{array}{l}\text { Group 2 } \\
(\mathbf{n}=\mathbf{2 0})\end{array}$ & $\begin{array}{l}\text { Group 3 } \\
(\mathbf{n}=\mathbf{2 0})\end{array}$ & $\begin{array}{l}\text { Group 4 } \\
(\mathbf{n}=\mathbf{2 0})\end{array}$ & $\begin{array}{l}\text { Statistical } \\
\text { significance }\end{array}$ \\
\hline Age & $\mathbf{4 0 . 7 6} \pm \mathbf{5 . 8}$ & $\mathbf{4 1 . 1 0} \pm \mathbf{7 . 0}$ & $\mathbf{4 1 . 0 6} \pm 7.2$ & $\mathbf{4 0 . 8 2} \pm \mathbf{8 . 1}$ & $\mathbf{P}=\mathbf{0 . 9 8 6}$ \\
\hline Sex (Male/Female) & $11 / 9$ & $10 / 10$ & $11 / 9$ & $8 / 12$ & $\begin{array}{l}\mathbf{X}^{2}=\mathbf{0 . 9 7 3} \\
\mathbf{P}=\mathbf{0 . 8 2 3}\end{array}$ \\
\hline
\end{tabular}

$\mathrm{n}=$ number of subjects

Table 2: Table showing Mean \pm SD changes in Heart rate in groups 1, 2, 3 (Study) and group 4 (Control)

\begin{tabular}{|l|l|l|}
\hline HEART RATE & $\begin{array}{c}\text { Groups 1,2,3 } \\
\text { STUDY } \\
\text { Mean } \pm \text { S.D }\end{array}$ & $\begin{array}{l}\text { Group 4 } \\
\text { CONTROL } \\
\text { Mean } \pm \text { S.D }\end{array}$ \\
\hline Baseline & $86.5 \pm 12.1$ & $87.0 \pm 11.3^{\mathrm{NS}}$ \\
\hline After L \& I & $103.0 \pm 8.1$ & $118.0 \pm 14.2^{\mathrm{a}}$ \\
\hline After 1 MIN & $100.2 \pm 7.8$ & $113.6 \pm 14.6^{\mathrm{a}}$ \\
\hline After 2 MIN & $96.0 \pm 6.2$ & $106.7 \pm 11.5^{\mathrm{a}}$ \\
\hline After 3 MIN & $92.2 \pm 5.3$ & $99.3 \pm 9.8^{\mathrm{a}}$ \\
\hline After 5 MIN & $\mathbf{8 8 . 9} \pm 4.2$ & $95.2 \pm 7.8^{\mathrm{a}}$ \\
\hline
\end{tabular}

*Laryngoscopy and Intubation

a $=$ Highly significant $(p<0.001)$

NS = Not significant $(p>0.05)$

Table 3 Table showing Mean \pm SD changes in Heart rate in groups 1, 2, 3 (ANOVA)

\begin{tabular}{|l|l|l|l|l|}
\hline \multirow{2}{*}{ HEART RATE } & $\begin{array}{l}\text { Group 1 } \\
\text { Mean }\end{array}$ & $\begin{array}{l}\text { Group 2 } \\
\text { Mean }\end{array}$ & $\begin{array}{l}\text { Group 3 } \\
\text { Mean }\end{array}$ & $\begin{array}{l}\text { P } \\
\text { Value }^{\sharp}\end{array}$ \\
\cline { 2 - 5 } & 86.8 & 85.9 & 88.0 & 0.839 \\
\hline After L \& I* & 103.1 & 103.2 & 102.8 & 0.989 \\
\hline After 1 MIN & 100.4 & 100.2 & 100,0 & 0.989 \\
\hline After 2 MIN & 96.1 & 95.4 & 96.4 & 0.867 \\
\hline After 3 MIN & 92.0 & 91.3 & 93.3 & 0.411 \\
\hline After 5 MIN & 88.8 & 88.1 & 89,9 & 0.338 \\
\hline
\end{tabular}

\footnotetext{
*Laryngoscopy and Intubation

${ }^{\#} P$ values $>0.05$ are insignificant
} 
Table 4 Table showing Mean \pm SD changes in Systolic blood pressure in groups 1, 2, 3 (Study) and group 4 (Control)

\begin{tabular}{|l|l|l|}
\hline $\begin{array}{l}\text { SYSTOLIC BLOOD } \\
\text { PRESSURE }\end{array}$ & $\begin{array}{l}\text { Groups 1,2,3 } \\
\text { STUDY } \\
\text { Mean } \pm \text { S.D }\end{array}$ & $\begin{array}{l}\text { Group 4 } \\
\text { CONTROL } \\
\text { Mean } \pm \text { S.D }\end{array}$ \\
\hline Baseline & $127.1 \pm 8.5$ & $128.2 \pm 7.1^{\text {NS }}$ \\
\hline After L \& I* & $141.6 \pm 7.0$ & $161.2 \pm 5.7^{\mathrm{a}}$ \\
\hline After 1 MIN & $138.6 \pm 6.6$ & $155.4 \pm 5.6^{\mathrm{a}}$ \\
\hline After 2 MIN & $135.8 \pm 6.0$ & $149.6 \pm 5.6^{\mathrm{a}}$ \\
\hline After 3 MIN & $132.9 \pm 5.6$ & $144.9 \pm 5.1^{\mathrm{a}}$ \\
\hline After 5 MIN & $131.8 \pm 5.7$ & $140.8 \pm 6.4^{\mathrm{a}}$ \\
\hline
\end{tabular}

*Laryngoscopy and Intubation

a = Highly significant $(\mathbf{p}<\mathbf{0 . 0 0 1})$

$\mathrm{NS}=$ Not significant $(\mathbf{p}>\mathbf{0 . 0 5})$

Table 5 Table showing Mean \pm SD changes in Systolic blood pressure in groups 1, 2, 3 (ANOVA)

\begin{tabular}{|l|l|l|l|l|}
\hline $\begin{array}{l}\text { SYSTOLIC } \\
\text { BLOOD } \\
\text { PRESSURE }\end{array}$ & $\begin{array}{l}\text { Group 1 } \\
\text { Mean }\end{array}$ & $\begin{array}{l}\text { Group 2 } \\
\text { Mean }\end{array}$ & $\begin{array}{l}\text { Group 3 } \\
\text { Mean }\end{array}$ & P Value \\
\hline Baseline & 125.8 & 126.9 & 128.7 & 0.578 \\
\hline After L \& I* & 140.2 & 141.7 & 143.0 & $<0.001$ \\
\hline After 1 MIN & 137.3 & 138.6 & 139.8 & $<0.001$ \\
\hline After 2 MIN & 134.6 & 135.8 & 136.8 & $<0.001$ \\
\hline After 3 MIN & 132.0 & 132.7 & 133.9 & $<0.001$ \\
\hline After 5 MIN & 130.6 & 131.2 & 133.4 & $<0.001$ \\
\hline
\end{tabular}

\section{*Laryngoscopy and Intubation}

\# $P$ values $>0.05$ are insignificant

Table 6 Table showing Mean \pm SD changes in Diastolic Blood Pressure in groups 1, 2, 3 (Study) and group 4 (Control)

\begin{tabular}{|l|l|l|}
\hline $\begin{array}{l}\text { DIASTOLIC BLOOD } \\
\text { PRESSURE }\end{array}$ & $\begin{array}{l}\text { Groups 1,2,3 } \\
\text { STUDY } \\
\text { Mean } \pm \text { S.D }\end{array}$ & $\begin{array}{l}\text { Group 4 } \\
\text { CONTROL } \\
\text { Mean } \pm \text { S.D }\end{array}$ \\
\hline Baseline & $81.3 \pm 7.5$ & $\mathbf{8 1 . 8} \pm 6.7^{\mathrm{NS}}$ \\
\hline After L \& I* & $93.4 \pm 7.4$ & $105.3 \pm 6.1^{\mathrm{a}}$ \\
\hline After 1 MIN & $90.8 \pm 7.0$ & $100.6 \pm 4.7^{\mathrm{a}}$ \\
\hline After 2 MIN & $\mathbf{8 7 . 6} \pm 6.9$ & $96.3 \pm 4.9^{\mathrm{a}}$ \\
\hline After 3 MIN & $\mathbf{8 5 . 3} \pm 6.5$ & $91.9 \pm 5.0^{\mathrm{a}}$ \\
\hline After 5 MIN & $\mathbf{8 2 . 9} \pm 6.4$ & $87.8 \pm 4.9^{\mathrm{a}}$ \\
\hline
\end{tabular}

\footnotetext{
*Laryngoscopy and Intubation

$a=$ Highly significant $(p<0.001)$

$\mathrm{NS}=$ Not significant $(p>0.05)$
} 
Table 7 Table showing Mean \pm SD changes in Diastolic Blood Pressure in groups 1, 2, 3 (ANOVA)

\begin{tabular}{|l|l|l|l|l|}
\hline $\begin{array}{l}\text { DIASTOLIC } \\
\text { BLOOD } \\
\text { PRESSURE }\end{array}$ & $\begin{array}{l}\text { Group 1 } \\
\text { Mean }\end{array}$ & $\begin{array}{l}\text { Group 2 } \\
\text { Mean }\end{array}$ & $\begin{array}{l}\text { Group 3 } \\
\text { Mean }\end{array}$ & P Value $^{\#}$ \\
\hline Baseline & $\mathbf{8 0 . 8}$ & 80.7 & 82.5 & 0.807 \\
\hline After L \& I & $\mathbf{9 3 . 0}$ & 92.9 & 94.3 & $<0.001$ \\
\hline After 1 MIN & 90.4 & 90.5 & 91.5 & $<0.001$ \\
\hline After 2 MIN & $\mathbf{8 7 . 7}$ & 87.0 & $\mathbf{8 8 . 0}$ & $<0.001$ \\
\hline After 3 MIN & $\mathbf{8 5 . 4}$ & $\mathbf{8 4 . 7}$ & $\mathbf{8 5 . 8}$ & $<0.001$ \\
\hline After 5 MIN & $\mathbf{8 3 . 0}$ & $\mathbf{8 2 . 3}$ & $\mathbf{8 3 . 6}$ & $<0.001$ \\
\hline
\end{tabular}

*Laryngoscopy and Intubation

${ }^{\#} \mathbf{P}$ values $>\mathbf{0 . 0 5}$ are insignificant

Table 8 Table showing Mean \pm SD changes in Mean Arterial Pressure in groups 1, 2, 3 (Study) and group 4 (Control)

\begin{tabular}{|l|l|l|}
\hline $\begin{array}{l}\text { Mean } \\
\text { pressure }\end{array}$ & $\begin{array}{l}\text { arterial } \\
\text { Groups 1,2,3 } \\
\text { Mean } \pm \text { S.D }\end{array}$ & $\begin{array}{l}\text { Group 4 } \\
\text { CONTROL } \\
\text { Mean } \pm \text { S.D }\end{array}$ \\
\hline Baseline & $97.6 \pm 6.8$ & $97.2 \pm 5.6^{\mathrm{NS}}$ \\
\hline After L \& I* & $109.5 \pm 6.2$ & $123.9 \pm 5.3^{\mathrm{a}}$ \\
\hline After 1 MIN & $106.7 \pm 5.8$ & $118.9 \pm 4.0^{\mathrm{a}}$ \\
\hline After 2 MIN & $103.6 \pm 5.7$ & $114.0 \pm 4.2^{\mathrm{a}}$ \\
\hline After 3 MIN & $101.1 \pm 5.2$ & $109.6 \pm 4.0^{\mathrm{a}}$ \\
\hline After 5 MIN & $99.2 \pm 5.1$ & $105.5 \pm 4.0^{\mathrm{a}}$ \\
\hline
\end{tabular}

*Laryngoscopy and Intubation

a = Highly significant $(\mathbf{p}<0.001)$

NS $=$ Not significant $(\mathbf{p}>\mathbf{0 . 0 5})$

Table 9 Table showing Mean \pm SD changes in Mean Arterial Pressure in groups 1, 2, 3 (ANOVA)

"Laryngoscopy and Intubation

\begin{tabular}{|l|l|l|l|l|}
\hline $\begin{array}{l}\text { Mean arterial } \\
\text { pressure }\end{array}$ & $\begin{array}{l}\text { Group 1 } \\
\text { Mean }\end{array}$ & $\begin{array}{l}\text { Group 2 } \\
\text { Mean }\end{array}$ & $\begin{array}{l}\text { Group 3 } \\
\text { Mean }\end{array}$ & $\begin{array}{l}\text { P } \\
\text { Value }^{\#}\end{array}$ \\
\hline Baseline & 95.8 & 96.1 & 97.9 & 0.496 \\
\hline After L \& I & 108.7 & 109.2 & 110.6 & 0.553 \\
\hline After 1 MIN & 106.1 & 106.5 & 107.6 & 0.641 \\
\hline After 2 MIN & 103.3 & 103.3 & 104.3 & 0.780 \\
\hline After 3 MIN & 100.9 & 100.7 & 101.8 & 0.713 \\
\hline After 5 MIN & 98.9 & 98.6 & 100.2 & 0.501 \\
\hline
\end{tabular}

${ }^{\#} \mathbf{P}$ values $>0.05$ are insignificant 
Mean \pm SD changes in Heart rate in groups 1, 2, 3 (Study) and group 4 (Control)

\section{Heart rate}

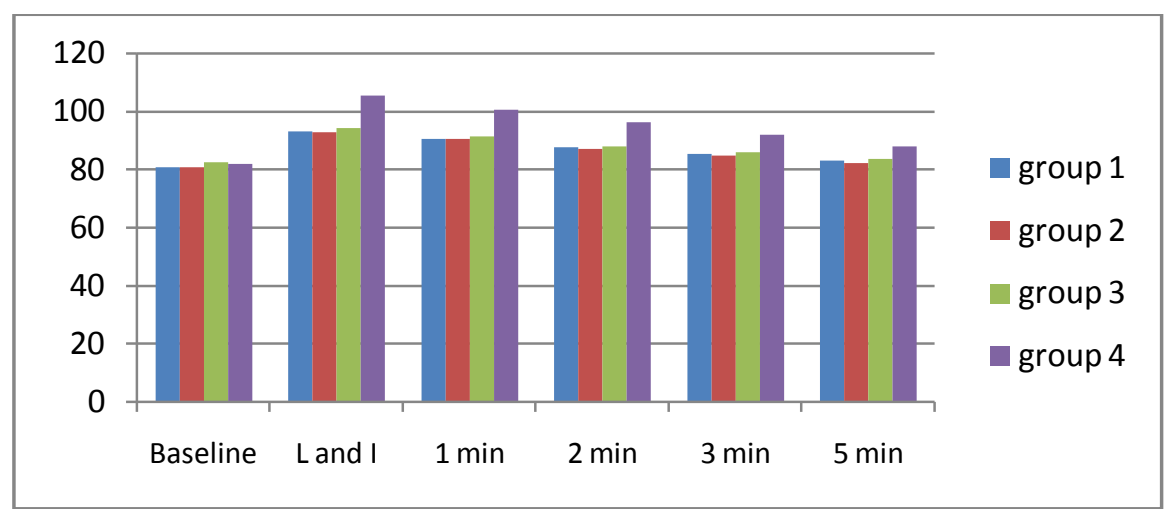

Mean \pm SD changes in Systolic blood pressure in groups 1, 2, 3 (Study) and group 4 (Control) Systolic BP

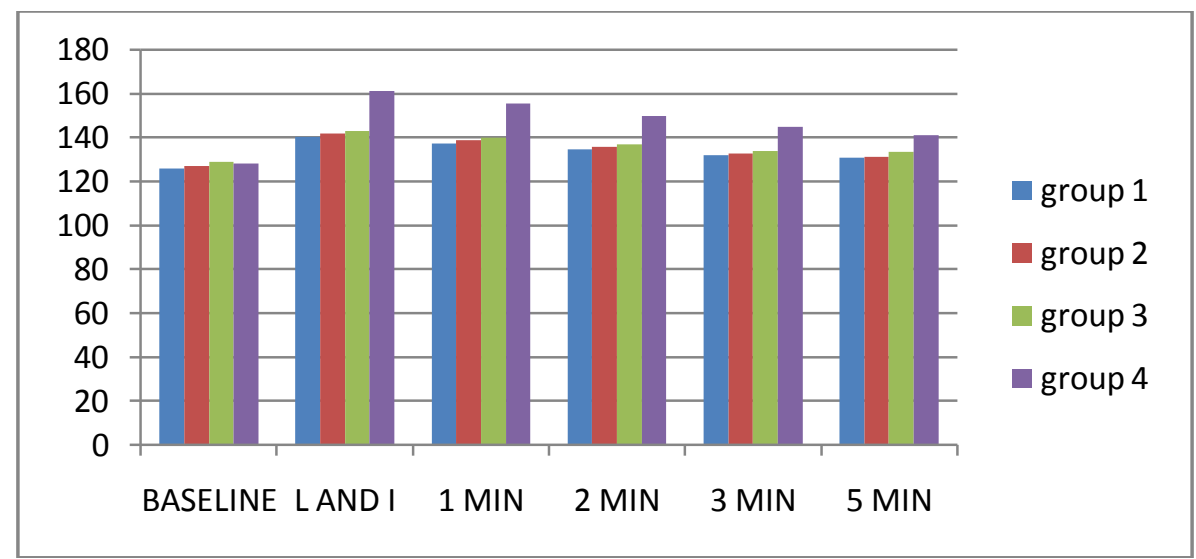

Mean \pm SD changes in Diastolic Blood Pressure in groups 1, 2, 3 (Study) and group 4 (Control) Diastolic blood pressure

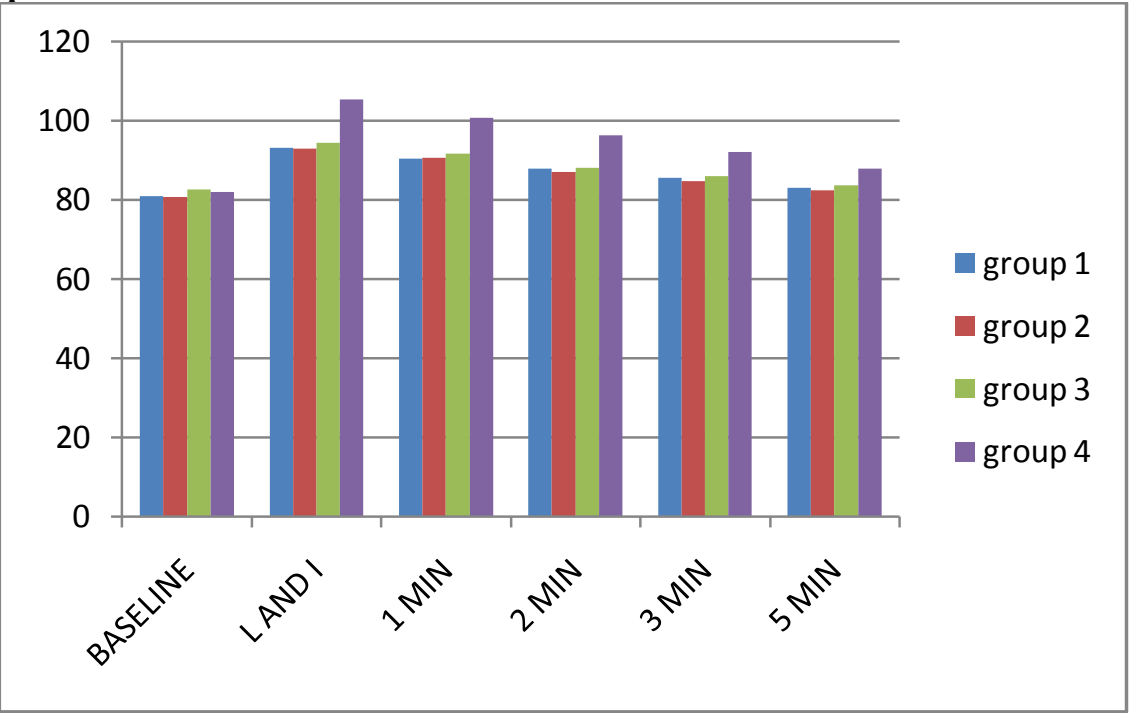


Mean \pm SD changes in Mean Arterial Pressure in groups 1, 2, 3 (Study) and group 4 (Control)

\section{Mean arterial pressure}

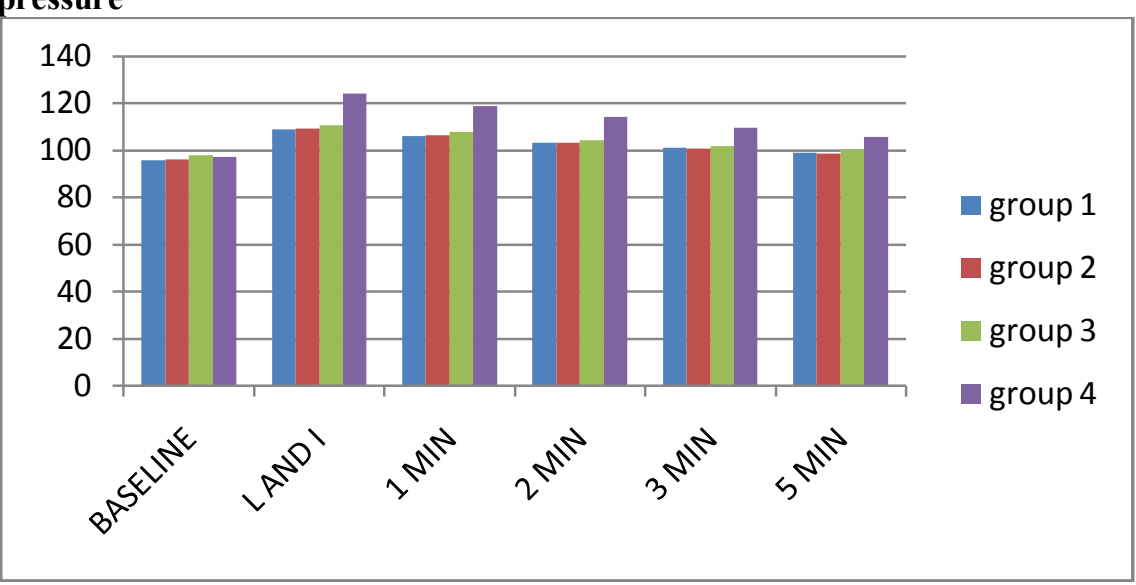

\section{References}

[1]. Hassan, H. G., El-Sharkawy, T. Y., Renck, H., Mansour, G. and Fouda, A. (1991), Hemodynamic and catecholamine responses to laryngoscopy with vs. without endotracheal intubation. Acta Anaesthesiologica Scandinavica, 35: 442-447. doi: 10.1111/j.13996576.1991.tb03325.x.

[2]. Mi WD, Sakai T, Takahashi S, Matsuki A,Haemodynamic and electroencephalograph responses to intubation during induction with propofol or propofol/fentanyl. Can J Anaesth 1998; 45:19.

[3]. Wilson IG, Meiklejohn BH, Smith G: Intravenous lignocaine and sympathoadrenal responses to laryngoscopy and intubation. The effect of varying time of injection. Anaesthesia. 1991 Mar;46(3):177-180.

[4]. Shribman AJ, Smith G, Achola KJ: Cardiovascular and catecholamine responses to laryngoscopy with and without tracheal intubation. Br J Anaesth 1987; 59:295.

[5]. King BD, Harris LC, Greifenstein FE, Elder JD, Dripps RD. Reflex circulatory responses to direct laryngoscopy and tracheal intubation performed during general anesthesia. Anesthesiology 1951; 12:556-566.

[6]. Stoelting RK. Circulatory changes during direct laryngosocpy and tracheal intubation - influence of duration of laryngoscopy with or without prior lidocaine. Anesthesiology 1977; 47(4): 381-384.

[7]. RavalDipak L., Mehta Malini K. Oral clonidine pre medication for attenuation of haemodynamic response to laryngoscopy and intubation.Indian J. Anaesth. 2002; 46 (2) : 124-124.

[8]. Carabine UA, Allen RW, Moore J. Partial attenuation of the pressor response to endotracheal intubation. A comparison of the effects of intravenous clonidine and fentanyl. Eur J Anaesthesiol. 1992 Jul;9(4):325-329.

[9]. Vucevic M, Purdy GM, Ellis FR. Esmolol hydrochloride for management of the cardiovascular stress responses to laryngoscopy and tracheal intubation. Br J Anaesth1992; 68: 529-530.

[10]. Braude N, Clements EAF, Hodges UM, Andrews BP. The pressor response and laryngeal mask insertion - a comparison with tracheal intubation Anaesthesia, 1989; 44: 551-554.

[11]. S. Singhal, .Neha: Haemodynamic Response To Laryngoscopy And Intubation: Comparison Of McCoy And Macintosh Laryngoscope. The Internet Journal of Anesthesiology. 2008 Volume 17 Number 1. DOI: 10.5580/107d

[12]. Fassoulaki A, KaniarisP.Intranasal administration of nitroglycerine attenuates the pressor response to laryngoscopy and intubation of the trachea.Br J Anaesth. 1983 Jan;55(1):49-52.

[13]. Lev R, Rosen P. Prophylactic lidocaine use preintubation: a review. J Emerg Med. Jul-Aug 1994;12(4):499-506

[14]. Abou-Madi MN, Keszler H, Yacoub JM. Cardiovascular reactions to laryngoscopy and tracheal intubation following small and large intravenous doses of lidocaine. Can AnaesthSoc J 1977;24: 12-19.

[15]. Watanabe H, Lindgren L, Rosenberg P, Randell T. Glycopyrronium prolongs topical anaesthesia of oral mucosa and enhances absorption of lignocaine. British Journal of Anaesthesia 1993; 70: 94-5.

[16]. Mostafa SM, Murthy BVS, Barrett PJ, McHugh P. Comparison of the effects of topical Lignocaine spray applied before or after induction of anaesthesia on pressor response to direct laryngoscopy and intubation Eur J Anaesthesiol.1999;16:7-10.

[17]. Hamill JF,BedfordRF, Weaver DC. Lidocaine before endotracheal intubation: Intravenous or Laryngotracheal. Anaesthesiology 1981; 55:578-581.

[18]. Takita K, Morimoto Y,Kemmotsu O. Tracheal Lidocaine attenuates the cardiovascular response to endotracheal intubation. CJA 2001:48(8):732-736.

[19]. M. Jain, S.A. Gurcoo, A.N. Shora, M.S. Qazi, B.A. Dar, V.N. Buchh, S.I. Ahmad. Efficacy Of Topical Lignocaine Spray (10\%) Applied Before The Induction Of Anaesthesia In Attenuating The Pressor Response To Direct Laryngoscopy And Endotracheal Intubation In Controlled Hypertensive Patients. The Internet Journal of Anesthesiology. 2009, 20(2) DOI: 10.5580/25bc 